\title{
(GTG)5-PCR Mediated Molecular Typing of Zoonotic Bacteria
}

\author{
Daryoush Babazadeh ${ }^{1}$ and Reza Ranjbar ${ }^{2 *}$ \\ ${ }^{I}$ PhD, Faculty of Veterinary Medicine, Shiraz University, Shiraz, Iran \\ ${ }^{2}$ PhD, Molecular Biology Research Center, Systems Biology and Poisonings Institute, Baqiyatallah University of Medical Sciences, Tehran, Iran \\ *Corresponding author's Email: ranjbarre@gmail.com; (DORCID: 0000-0001-8593-1514
}

\begin{abstract}
The present review aimed to reveal the role of $(\mathrm{GTG})_{5}$-PCR microbial typing in indicating the routes and source of infections, investigate the outbreaks and genotypes of clinical strains, as well as finding virulent strains and epidemiology of bacterial isolates. All available and published data in Google scholar, PubMed, ResearchGate, and Science Direct during the past two decades that used the (GTG) ${ }_{5^{-}}$ PCR method for genotyping the bacterial isolates were included in the current study. The findings have indicated that $(\mathrm{GTG})_{5}$-PCR can be recommended as a possible, cost-effective, fast, and easy tool for molecular typing of bacterial isolates.
\end{abstract}

Keywords: Zoonotic bacteria, (GTG) $)_{5}$ PCR, Molecular typing

\section{INTRODUCTION}

It is of utmost importance to understand clonal relatedness between the microbial strains since it can help to identify the source and routes of infections, examine the outbreaks, detect cross-transmission of healthcareassociated pathogens, distinguish particularly virulent strains and assess the efficacy of control measures (Tenover et al., 1997; MacCannell, 2013; Rafei et al., 2014). Bacterial typing has also helped in the improvement of monitoring programs and provided important data for public health prevention strategies.

The traditional typing methods were based on phenotypic typing while modern molecular methods are based on genome components of bacteria (Bradford, 2018). Antibiogram, biotyping, serotyping, and phage typing are examples of traditional epidemiological typing methods that have sometimes been effective in understanding the epidemiology of infectious diseases. Serotyping, phage typing, and antibiotic resistance patterns could provide useful information for short-term epidemiological studies in pathogens worldwide (Tenover et al., 1997; MacCannell, 2013). However, conventional methods are of various types, which are labor-intensive and timeconsuming in epidemiological investigations (MacCannell, 2013). As a result, DNA-based typing methods play a significant role in the analysis of most microbial pathogens' epidemiology.

Numerous epidemiological typing systems have been used, with a diverse armamentarium ranging from nonmolecular techniques to more advanced molecular typing technologies. The most widely utilized molecular typing methods include the DNA-based methods, particularly restriction endonuclease analysis of genomic and plasmid DNA, southern hybridization analysis with the use of specific DNA probes, plasmid profiling, chromosomal DNA profiling using either pulse-field gel electrophoresis or polymerase chain reaction (PCR)-based methods (Tenover et al., 1997; MacCannell, 2013). Molecular genetic techniques, such as PCR, nucleic acid fingerprinting, DNA sequence analysis of bacterial chromosomes are important techniques in identifying the prevalence of nosocomial infections, food contamination reservoirs or the release of pathogenic plant strains into the environment, and isolation of specific genotypes in conjugation with a particular bacterium (Ranjbar et al., 2008).

However, the aforementioned methods also have been recognized with some disadvantages, such as the need for special tools, considerable cost, and time-consuming procedure. Regarding this background, the present study aimed to review the importance of using $(\mathrm{GTG})_{5}$-PCR as a simple and low-cost method for subtyping bacterial isolates.

\section{Sources}

All available and published data in Google scholar, PubMed, ResearchGate, and ScienceDirect that used the (GTG) $)_{5}$-PCR method for genotypes of $A$. baumannii isolates were included in the current study. 


\section{Subtyping of bacterial isolates}

Genetic variation in the genome of bacteria causes a molecular typing method to determine bacterial strains. For microbial typing of bacteria, many approaches are available; however, each of them has its own merits and demerits that make it useful in some studies and restrictive in others. High discriminatory power, good reproducibility, the simplicity of the method, simple interpretation of the results, and low costs of the method are important issues to choose an approach as a typing method (Li et al., 2009).

\section{(GTG) $)_{5}$-PCR}

This method is effective in screening a large number of bacterial strains and it is beneficial for intraspecies differentiation and identification of bacterial genomes. Indeed, (GTG) $)_{5}$ PCR is a type of repetitive extragenic palindromic (rep)-PCR that amplifies the $(\mathrm{GTG})_{5}$ repetitive element which lays throughout the bacterial genomes (Gevers et al., 2001). This PCR-based method can be used for a broad range of Gram-negative bacteria and a narrow range of Gram-positive bacteria (Gevers et al., 2001; Kathleen et al., 2014).

\section{Acinetobacter baumannii}

There are a few studies on molecular typing of A. baumannii using the (GTG) ${ }_{5}$-PCR. Huys et al. (2009) presented that $(\mathrm{GTG})_{5}$-PCR was a reliable and cost-efficient tool to differentiate members of pan-European multi-resistant $A$. baumannii (MAB) clone III from different MAB clones isolated from the University Hospital of Ghent, Belgium (Huys et al., 2009). In another study, the (GTG) $)_{5}$-PCR-based typing method was used to differentiate A. baumannii strains recovered from hospitals of Tehran, Iran. The findings of this research highlighted the high power of typing since more than $95 \%$ of the isolates were typable and (GTG) $)_{5}$-PCR differentiated the strains into $13(\mathrm{GTG})_{5}$ clusters (Ranjbar and Babazadeh, 2021).

\section{Staphylococcus species}

The highly resistant coagulase-negative staphylococci are important factors of nosocomial diseases and veterinary infections. The identification of staphylococcal species using traditional biochemical tests is not efficient due to the increase in the number of known subspecies. There are many reports for genotypic and phenotypic detection of staphylococci (Braem et al., 2011). A study conducted on 35 type strains and 253 field isolates of Staphylococcus species indicated (GTG) $)_{5}$-PCR fingerprinting is a useful method to determine the identity of bovine Staphylococcus species. (GTG) $)_{5}$-PCR fingerprinting achieved a typeability of $94.7 \%$ and an accuracy of $94.3 \%$, compared to identifications based on gene sequencing in this study (Stepán et al., 2004). Nováková et al. (2010) By using rep-PCR using the (GTG)5 primer could differentiate Staphylococcus microti DSM 22147 from viscera of common voles.

\section{Lactobacilli species}

Svec et al. (2011) used the (GTG) $)_{5}$-PCR to characterize vaginal lactobacilli. It is declared that $(\mathrm{GTG})_{5}$-PCR is a simple, beneficial, and rapid method for the identification of many vaginal lactobacilli isolates and also suggested that this method can be more reliable in combination with other techniques (Svec et al., 2008; Svec et al., 2011).

\section{Salmonella species}

Salmonella enterica Serotype 4,[5],12:i:- is an emerging serotype with worldwide distribution and a significant infection rate of humans and domestic animals (Yang et al., 2015). The methods of BOX-A1R-based (BOX)-PCR, repetitive extragenic palindromic (REP)-PCR, enterobacterial repetitive intergenic consensus (ERIC)-PCR, and GTG5PCR were compared in a study. The findings indicated that both the high average number of amplicons bands and high value of discrimination index suggested BOX-PCR and GTG5-PCR as better molecular typing methods than REP-PCR and ERIC-PCR in their capability to distinguish among closely genetically related $S .4$,[5], 12:i:- isolates in hospitalized patients and minced pork samples. Also, BOX-PCR and GTG5- PCR generated more clusters for each serotype from the same and different sources (Poonchareon et al., 2019).

\section{Klebsiella species}

Klebsiella pneumoniae is a Gram-negative nosocomial pathogen detected in many infectious diseases, such as bacteremia, pneumonia, urinary tract infections, and in patients with underlying diseases (Shakib et al., 2012; Mancini et al., 2018). The pathogenicity of this organism is notable because of its ability to produce some important enzymes which destroy an extended spectrum of antimicrobial agents (Shakib et al., 2012). In a study, 88 K. pneumoniae isolates were subjected to $(\mathrm{GTG})_{5}-\mathrm{PCR}$ assay, and the strains were differentiated into 9 clusters which showed the ability of this method for molecular typing of K. pneumoniae strains (Ranjbar and Afshar, 2019). 


\section{Streptococcus species}

Svec et al. (2008) evaluated the (GTG) $)_{5}$ PCR for the fast screening of bacterial strains isolated from dental plaque of children with early childhood caries. It is proposed that the (GTG) ${ }_{5}$-PCR fingerprinting is a fast and valid method for the identification of Streptococcus Mutans, compared to other used molecular typing methods (Svec et al., 2008).

\section{Campylobacter species}

Campylobacteriosis is one of the most common zoonotic diseases derived from the consumption of contaminated poultry meat (Poonchareon et al., 2019). There are few studies that assay the Campylobacter species via (GTG) 5-PCR. In one study conducted in Cape Town for eight years, DNA fingerprinting using (GTG) 5 was performed to type 100 isolates of Campylobacter concisus strains. The findings of a study conducted by Matsheka et al. (2006) provided that homologous lineages of $C$. concisus may belong to a heterogeneous species complex. The mentioned study also confirmed the discriminability and simplicity of (GTG) $)_{5}$-PCR (Matsheka et al., 2006).

\section{Escherichia coli}

Extraintestinal Escherichia coli, the main cause of colibacillosis in chickens, also cause different infections in humans, such as neonatal meningitis, urinary tract infections, and sepsis (Mellata, 2013). Knowing the abundance of this bacterium in its natural source is very strategical for controlling the occurrence of infectious agents in humans and animals. A study on the feces of many poultry and free-living birds revealed that from $95 \%$ to $70.7 \%$ of fecal E. coli isolates were classified into the correct host source (Mohapatra et al., 2008).

\section{Enterococcus species}

Many phenotypic and molecular methods have been described for the identification of enterococci (Domig et al., 2003). The rep-PCR with (GTG) $)_{5}$ primer has also been presented as a reliable method for species identification of all enterococci strains which grouped clearly into well-separated clusters and representing single species (Švec et al., 2005).

\section{Yersinia species}

Huang et al. (2013) analyzed the variation of molecular characteristics of Yersinia ruckeri isolates collected in northwest Germany and reported that this method was one of the best methods of molecular typing, compared to the methods which could obtain four patterns of Yersinia ruckeri isolates. In order to compare the obtained molecular profiles of Yersinia enterocolitica, rep-PCR method was suggested using the primer (GTG) 5 (Versalovic et al., 1994). Regarding rep-PCR, the comparison revealed that the contaminated pigs with Yersinia enterocolitica could carry the microorganism to different points in the abattoir environment (Moreira et al., 2019).

\section{Vibrio species}

Ben-Haim et al. (2003) studied the Vibrio coralliilyticus species and found that the inner AFLP and GTG5-PCR pattern similarities were higher than $64 \%$. Balcázar et al. (2010) suggested that rep-PCR fingerprinting technique using (GTG)5-PCR allowed differentiating $V$. alginolyticus and V. splendidus in epidemiological analyses, particularly in large studies and critical situations.

\section{Other bacterial species}

Kathleen et al. (2014) reported (GTG)5 PCR is useful in the differentiation of unknown bacterial isolates. De Vuyst et al. (2008) found some new Acetobacter species and reported (GTG)5-PCR DNA fingerprinting was useful for the identification and classification of acetic acid bacteria to the species level. Acetic acid bacteria Gram-negative, ellipsoidal to rod-shaped, obligate aerobic bacteria that currently classified into 10 genera and 44 species, such as Acetobacter and, Gluconacetobacter species. It is reported Rep-PCR using (GTG) 5 could provide better differentiation of the isolates of Listeria monocytogenes than did RAPD PCR and resulted in discrimination of the isolates into a larger number of unique profiles (Hadjilouka et al., 2014).

\section{CONCLUSION}

The current study supports the idea that $(\mathrm{GTG})_{5}$-PCR is a possible, cost-effective, and easy technique for molecular typing of bacterial isolates; however, these data can be compared to more known typing techniques.

\section{DECLARATION}

\section{Author's contribution}

Daryoush Babazadeh reviewed the articles and wrote the draft of the manuscript. Reza Ranjbar revised the draft of the manuscript and prepared it for submission. All authors check and confirmed the final version of the manuscript. 


\section{Competing interests}

The authors declare that they have no competing interests.

\section{Acknowledgments}

We would like to thank the Clinical Research Development Unit of Baqiyatallah University of medical science for their kindly cooperation.

\section{Consent to publish}

Not applicable.

\section{REFERENCES}

Balcázar JL, Gallo-Bueno A, Planas M and Pintado J (2010). Isolation of Vibrio alginolyticus and Vibrio splendidus from captivebred seahorses with disease symptoms. Antonie van Leeuwenhoek, 97: article number 207. DOI: https://doi.org/10.1007/s10482$\underline{009-9398-4}$

Ben-Haim Y, Thompson FL, Thompson CC, Cnockaert MC, Hoste B, Swings J, and Rosenberg E (2003). Vibrio coralliilyticus sp. nov., a temperature-dependent pathogen of the coral Pocillopora damicornis. International Journal of Systematic and Evolutionary Microbiology, 53: 309-315. DOI: https://doi.org/10.1099/ijs.0.02402-0

Bradford PA (2018). Epidemiology of Bacterial Resistance. In, Fong I., Shlaes D., Drlica K. (Eds) Antimicrobial Resistance in the 21 st Century. Emerging Infectious Diseases of the $21 \mathrm{st}$ Century. Springer, Cham. Available at: https://www.springer.com/gp/book/9783319785370

Braem G, De Vliegher S, Supré K, Haesebrouck F, Leroy F, and De Vuyst L (2011). (GTG) 5-PCR fingerprinting for the classification and identification of coagulase-negative Staphylococcus species from bovine milk and teat apices: a comparison of type strains and field isolates. Veterinary Microbiology, 147: 67-74. DOI: https://www.doi.org/10.1016/j.vetmic.2010.05.044

De Vuyst L, Camu N, De Winter T, Vandemeulebroecke K, Van de Perre V, Vancanneyt M, De Vos P, and Cleenwerck I (2007). Validation of the (GTG) (5)-rep-PCR fingerprinting technique for rapid classification and identification of acetic acid bacteria, with a focus on isolates from Ghanaian fermented cocoa beans. International Journal of Food Microbiology, 125(1):79-90. DOI: https://doi.org/10.1016/j.ijfoodmicro.2007.02.030

Domig KJ, Mayer HK, and Kneifel W (2003). Methods used for the isolation, enumeration, characterization and identification of Enterococcus spp. 2. Pheno- and genotypic criteria. International Journal of Food Microbiology, 88: 165-188. DOI: https://www.doi.org/ 10.1016/s0168-1605(03)00178-8.

Gevers D, Huys G, and Swings J (2001). Applicability of rep-PCR fingerprinting for identification of Lactobacillus species. FEMS Microbiology Letters, 205: 31-36. DOI: https://www.doi.org/10.1111/j.1574-6968.2001.tb10921.x

Hadjilouka A, Andritsos ND, Paramithiotis S, Mataragas M, and Drosinos EH (2014). Listeria monocytogenes serotype prevalence and biodiversity in diverse food products. Journal of Food Protection, 77(12): 2115-2120. DOI: https://doi.org/10.4315/0362028X.JFP-14-072

Huang Y, Runge M, Michael GB, Schwarz S, Jung, A and Steinhagen D (2013). Biochemical and molecular heterogeneity among isolates of Yersinia ruckeri from rainbow trout (Oncorhynchus mykiss, Walbaum) in north west Germany. BMC Veterinary Research, 9: Article number 215. DOI: https://doi.org/10.1186/1746-6148-9-215

Huys G, Cnockaert M, Nemec A, Dijkshoorn L, Brisse S, Vaneechoutte M, and Swings J (2005). Repetitive-DNA-element PCR fingerprinting and antibiotic resistance of pan-European multi-resistant A. baumannii clone III strains. Journal of Medical Microbiology, 54: 851-856. DOI: https://www.doi.org/10.1099/jmm.0.45986-0

Kathleen MM, Samuel L, Felecia C, Ng KH, Lesley MB, and Kasing A (2014). (GTG) 5-PCR analysis and 16S rRNA sequencing of bacteria from Sarawak aquaculture environment. International Food Research Journal, 21(3): 915-920. Available at http://www.ifrj.upm.edu.my/21\%20(03)\%202014/10\%20IFRJ\%2021\%20(03)\%202014\%20Kahleen\%20723.pdf

Kathleen MM, Samuel L, Felecia C, Ng KH, Lesley MB, and Kasing A (2014). (GTG)5-PCR analysis and 16S rRNA sequencing of bacteria from Sarawak aquaculture environment. International Food Research Journal, 21(3): 915-920.

Li W, Raoult D, and Fournier PE (2009). Bacterial strain typing in the genomic era. FEMS Microbiol Review, 33: 892-916. DOI: https://www.doi.org/10.1111/j.1574-6976.2009.00182.x

MacCannell D (2013). Bacterial strain typing. Clinics In Laboratory Medicine, 33(3): 629-650. DOI: https://www.doi.org/10.1016/j.cll.2013.03.005

Mancini S, Poirel L, Corthesy M, Greub G, and Nordmann P (2018). Klebsiella pneumoniae co-producing KPC and RmtG, finally targeting Switzerland. Diagnosis of Microbiology and Infectious Diseases, 90(2): 151-152. DOI: https://www.doi.org/10.1016/j.diagmicrobio.2017.10.019

Matsheka MI, Lastovica AJ, Zappe H, and Elisha BG (2006). The use of (GTG) 5 oligonucleotide as an RAPD primer to type Campylobacter concisus. Letters in Applied Microbiology, 42: 600-605. DOI: https://www.doi.org/10.1111/j.1472765X.2006.01900.X

Mellata M (2013). Human and avian extraintestinal pathogenic Escherichia coli: infections, zoonotic risks, and antibiotic resistance trends. Foodborne Pathogenes and Disease, 10: 916-932. DOI: https://www.doi.org/10.1089/fpd.2013.1533

Mohapatra BR, Broersma K, and Mazumder A (2008). Differentiation of fecal Escherichia coli from poultry and free-living birds by (GTG) 5-PCR genomic fingerprinting. International Journal of Medical Microbiology, 298: 245-252. DOI: https://www.doi.org/10.1016/j.ijmm.2007.03.019 
Moreira LM, Milan C, Gonçalves TG, Ebersol CN, de Lima HG, and Timm CD (2019). Contamination of pigs by Yersinia enterocolitica in the abattoir flowchart and its relation to the farm. Ciencia Rural, 49 (8). DOI: https://doi.org/10.1590/0103$\underline{8478 \mathrm{cr} 20181040}$

Nováková D, Pantůček R, Hubálek Z, Falsen E, Busse HJ, Schumann P, and Sedláček I (2010). Staphylococcus microti sp. nov., isolated from the common vole (Microtus arvalis). International Journal of Systematic and Evolutionary Microbiology, 60(Pt 3): 566-573. DOI: www.doi.org/10.1099/ijs.0.011429-0

Poonchareon K, Pulsrikarn C, Nuanmuang N, and Khamai P (2019). Effectiveness of BOX-PCR in differentiating genetic relatedness among Salmonella enterica serotype 4,[5], 12: i:-isolates from hospitalized patients and minced pork samples in northern Thailand. International Journal of Microbiology, Article ID: 5086240. DOI: https://www.doi.org/10.1155/2019/5086240

Rafei R, Dabboussi F, Hamze M, Eveillard M, Lemarié C, Gaultier MP, Mallat H, Moghnieh R, Husni-Samaha R, Joly-Guillou ML et al. (2014). Molecular analysis of Acinetobacter baumannii strains isolated in Lebanon using four different typing methods. PLoS One, 9(12): e115969. Available at: https://dx.plos.org/10.1371/journal.pone.0115969

Ranjbar R, Pourshafie M, Sadeghifard N, Parzadeh M, Izadi M, Jonaidi N, and Sedaghat M (2008). Molecular characterization of epidemic isolates of Vibrio cholerae O1 by Arbitrarily Primed PCR (AP-PCR). Iranian Journal of Public Health, 37: 83-87. DOI: https://www.doi.org10.5812/jjm.8(5)2015.18119

Ranjbar R, and Babazadeh D (2018). DNA fingerprinting of clinical strains of Acinetobacter baumannii isolated from some hospitals of Tehran, Iran by method of (GTG) $)_{5}$-PCR, thesis. 23-32. Available at: http://research2.bmsu.ac.ir/homepage/homePage.action

Ranjbar R, and Afshar D (2019). Evaluation of (GTG) 5-PCR for Genotyping of Klebsiella pneumonia Strains Isolated from Patients with Urinary Tract Infections. Iranian Journal of Public Health, 48(10): 1879-1884. DOI: https://doi.org/10.18502/ijph.v48i10.3496

Shakib P, Ghafourian S, Zolfaghary MR, Hushmandfar R, Ranjbar R, and Sadeghifard N (2012). Prevalence of OmpK35 and OmpK36 porin expression in beta-lactamase and non-betalactamase-producing Klebsiella pneumoniae. Biologics, 6: 1-4. DOI: https://www.doi.org/10.2147/BTT.S27582

Stepán J, Pantucek R, and Doskar J (2004). Molecular diagnostics of clinically important staphylococci. Folia Microbiologica, 49 : 353-386. Available at: https://link.springer.com/article/10.1007/BF03354664

Svec P, Nováková D, Zácková L, Kukletová M, and Sedlácek I (2008). Evaluation of (GTG) 5-PCR for rapid identification of Streptococcus mutans. Antonie Van Leeuwenhoek, 94: 573-579. DOI: https://www.doi.org/10.1007/s10482-008-9275-6

Svec P, Sedláček I, Chrápavá M, and Vandamme P (2011). (GTG) (5) -PCR fingerprinting of lactobacilli isolated from cervix of healthy women. Folia Microbiologica (Prague), 56: 80-83. DOI: https://www.doi.org/10.1007/s12223-011-0006-4

Švec P, Vancanneyt M, Seman M, Snauwaert C, Lefebvre K, Sedláček I, and Swings J (2005). Evaluation of (GTG) 5-PCR for $\begin{array}{llll}\text { identification of Enterococcus spp. FEMS Microbiology Letters, 247(1): 59-63. DOI: } & \end{array}$ https://www.doi.org/10.1016/j.femsle.2005.04.030

Tenover FC, Arbeit RD, and Goering RV (1997). How to select and interpret molecular strain typing methods for epidemiological studies of bacterial infections a review for healthcare epidemiologists. Infection Control and Hospital Epidemiology, 18(6): 426439. Available

at: http://cel.webofknowledge.com/InboundService.do?customersID=atyponcel\&smartRedirect=yes\&mode=FullRecord\&IsProduct Code=Yes\&product=CEL\&Init=Yes\&Func=Frame\&action=retrieve \&SrcApp=literatum \&SrcAuth=atyponcel \&SID=F39sOMH5 iQtkkKv1Sb6\&UT=WOS\%3AA1997XC21200008

Versalovic J, Schneider M, de Bruijn FJ, and Lupski JR (1994). Genomic fingerprinting of bacteria using repetitive sequence-based polymerase chain reaction. Methods in Molecular and Cellular Biology, 5: 25-40. Available at: https://www.scienceopen.com/document?vid=7a2acf61-8c89-4d19-89e1-f2987fdfa0f1

Yang X, Wu Q, Zhang J, Huang J, Guo W, and Cai S (2015). Prevalence and characterization of monophasic Salmonella serovar 1,4, [5], 12: i: -of food origin in China. PLoS One, 10(9): e0137967. Available at: https://journals.plos.org/plosone/article?id=10.1371/journal.pone. 0137967 